\title{
Human Resource Development through Novice Coach Education and Training in Indonesia
}

\author{
Dadi Darmadi*, Mohammad Fakry Gaffar, Amung Ma'mun, Nuryadi \\ Department of Sports Education, School of Postgraduate Studies, Universitas Pendidikan Indonesia, Indonesia
}

Received June 23, 2020; Revised August 10, 2020; Accepted August 25, 2020

\section{Cite This Paper in the following Citation Styles}

(a): [1] Dadi Darmadi, Mohammad Fakry Gaffar, Amung Ma'mun, Nuryadi , "Human Resource Development through Novice Coach Education and Training in Indonesia," International Journal of Human Movement and Sports Sciences, Vol. 8, No. 5, pp. 166 - 173, 2020. DOI: 10.13189/saj.2020.080502.

(b): Dadi Darmadi, Mohammad Fakry Gaffar, Amung Ma'mun, Nuryadi (2020). Human Resource Development through Novice Coach Education and Training in Indonesia. International Journal of Human Movement and Sports Sciences, 8(5), 166 - 173. DOI: 10.13189/saj.2020.080502.

Copyright $\odot 2020$ by authors, all rights reserved. Authors agree that this article remains permanently open access under the terms of the Creative Commons Attribution License 4.0 International License

\begin{abstract}
Coach is one of the supporting factors in creating outstanding athletes and improving sports achievements in Indonesia. The Ministry of Youth and Sports (Kemenpora) organized a training program that involved 100000 coaches and sport staffs. In this study, researchers focused on discussing what is meant by novice coach training; why novice coach training is absolutely pivotal; and what is the function of novice coach training. This research employed qualitative method. There were 150 participants involved in this study. They were the organizing committee, speakers, sports teachers, club coaches, and sports students. The instruments used in this research were document study, interview, and observation. From this research, it can be illustrated that the training of novice coaches is the flagship program of the Ministry of Youth and Sports which has been carried out as an effort to improve national sports achievements. Training is an activity designed to develop human resources through a series of planned identification, assessment, and learning processes. Novice coach training activities will motivate coaches, always improve their abilities and competencies and can create potential athletes in the future. With the existence of novice coaches training, it helps the local government, especially for KONI (National Sports Committee of Indonesia) in Regency/City level and the governing body of the sports branch for collecting data and mapping coaches. The coaches in this case are those who have not been well recorded.
\end{abstract}

Keywords Novice Coach, Sport Policy, Sports Achievements

\section{Introduction}

The national interest in the sports sector for Indonesia in global development is the ability to achieve high achievements in various competitions among participating countries. Sports excellence is a symbol of economic progress, science, technology, and civilization [1,2]. This is because sporting achievements involve the full collaboration of research, science, technology, education, economics, political policy, and social support from society to fight and excel in global competition [3,4]. Sports coaching must involve the aforementioned components which are then managed in a sophisticated, systematic, and modern way. The sophistication of its management is marked by the National Sport Policy and its elaboration into strategic planning with a long-term framework which is a dynamic process for realizing the vision of national sports. Neatly organized managerial and training programs that are full of innovation and applied sports science are demands for continuous improvement [5]. The coaching system must also be able to move the building of sports starting from upstream; starting from school sports, physical education, talent search and confirmation, expanding participation to increase the pool or barn of talented athletes to the development program of potential beginner athletes. The final destination of this effort is the high performance programs which are 
specifically prepared in order to take elite athletes to the International podium. Factors such as facilities and infrastructure, improvement of the quality of trainers, quality competition, sports science, character excellence and culture of champions, and the values of good sportsmanship must also be the top priority.

Achievements can be achieved if coaching programs have been established since an early age, started from the grass roots. One of the examples is tiered soccer competitions at various age levels, an increasing number of licensed coaches and referees, and also the provision of adequate sports infrastructure throughout Indonesia. The Ministry of Youth and Sports in the era of President Joko Widodo's leadership has started a program to improve sports achievements by referring to the Indonesian Centric concept which reflects the President's Nawacita that mandates Indonesia's development from the periphery through a program called 1 Desa 1 Lapangan/ 1 Village 1 Field [6]. In regard to the program to add licensed coaches and professional referees to be directed by the President, Kemenpora (Ministry of Youth and Sports) has established so through the Training Program for Referee, Coaches and Sports Staff that is currently still running and will be improved from both quality and quantity.

Creating athletes winning international achievements cannot be done instantly and suddenly. Athlete training should be carried out in a sustainable and tiered way through a modern and up-to-date process. High sports achievements cannot be separated from the training that is carried out as early as possible through the search and monitoring of talent, nursery, sports education and training based on the more effective science and technology. Creating good relationships between organizations and sports stakeholders, both at the central and regional levels is also an important factor in the concept of sustainable development. The training program of 100000 novice coaches and other sports personnel is one of the long-term programs to improve national sports achievements by strengthening the National Sports System (SKN). Through the strengthening of the National Sports System supported by sports personnel both in quantity and quality, specifically the development of educational sports and recreational sports becomes the foundation for the birth of national sports achievements [7].

Similar programs have already been implemented in developed countries such as the United States. They have implemented Instructional Coaching as part of the integration and collaboration of coaches and teachers in schools [8]. Instructional coaching is one way to provide support by professional coaches and a teacher whose aim is to improve student literacy skills, thereby increasing teaching and students' [9,10]. Instructional coaching supports and provides initial and ongoing professional development for teachers in each of the main reading components, administration and interpretation of instructional assessments, and differentiated instruction categories [11].

In sports, either coaches or teachers play a major role in providing safety interventions to players, motivate, and educate the application of technology as an effort to facilitate training and learning processes [12,13]. In addition, the coach also determines what specific activities the player must do during training to improve physical abilities, technical skills, and reduce the risk of injury [14]. Therefore, the comprehension of being a coach needs to be one of the special concerns in order to improve sports performance. The training program for 100,000 Indonesian novice coaches and sports instructors is a program designed by the government to increase the quantity and quality of coaches in Indonesia. It is interesting to examine the significance of the activity, the urgency, and the impact. Therefore, this study aimed at examining the three things: first, the definition of novice coaches; second, the importance and urgencies of novice coaches training program; and third, the implementation of the novice coach training program results.

\section{Materials and Methods}

This research employed qualitative design by exploring documents, phenomenal data and thoughts or opinions that are explored in the form of words, actions, documents, situations and events that can be observed [15]. Based on institutional and operational studies on novice coach training, the researchers determined six research objects, namely 1). Bandung City; 2). Sukabumi City; 3). Purwakarta Regency; 4). Kab, Sumedang; 5. Tasikmalaya City; and 6). Ciamis Regency. The selection of the 6 regions referred to the consideration of the existence of these areas that are located in West Java Province, making it easier for researchers to conduct research regularly in these regions.

The participants in this study were leaders of the stakeholders who have particular criteria. 150 people were involved as the research participants including, the training committee, the training speakers, the dean / the deputy deans 2 of FPOK-UPI, deputy assistant, head of achievement sports division, sports teachers / PJOK, club coaches from various sports such as football, basketball, volleyball, martial arts and so forth representing their respective regions and sports students.

Qualitative research method portrays researchers as the main instrument (human instrument), where researchers conduct their own research into the field to find the data and information needed [16]. Research instruments included 1). Document Review Guidelines; 2) Interview Guidelines; 3) Observation Guidelines; 4) Questionnaires.

The document review guidelines were used to review all documents that were already in the training committee's hands. With the document review guidelines, it means that researchers collect data by recording data 
that already exists; variables in the form of notes, transcripts, various government policy documents, regulations, minutes of meetings, agendas, and all documents about the development of national sports.

Interview guidelines were a guideline designed and compiled to explore more about unrevealed matters when conducting a document review and observation. Interview guidelines in the form of structured interviews asked questions to participants to explore data in the form of principles, thoughts, ideas, opinions, expectations, plans, or programs of the Ministry of Youth and Sports.

Observation guidelines were used to observe the activities of organizational actors in carrying out their main tasks and functions. Observation guidelines are instruments which are used to collect data about physical phenomena that can be directly observed.

The questionnaires were distributed to 150 respondents. The selection of respondents was based on the reasons that: (a) the respondents have time to answer questions or statements, (b) each respondent faces the same arrangement and method of filling in the questions addressed, (c) the respondents have the freedom to give answers, and (d) can be used to collect data or information from many respondents on a number of questions submitted in the questionnaire.

This study aimed to reveal contextual actions, events, empirical events, or objects in the field. Therefore, the data collected were descriptive and comprehensive. The steps taken in the data processing in this study were:

a). Data categorization and classification is to divide the data needed based on research questions in each area implementing novice coach training.

b). Verification was done by carefully checking the required data obtained through document review guidelines, interview guidelines, observation guidelines, and questionnaires, Whether the data are appropriate and relevant to the research question. If there is the data that has not been obtained or answered, it is recorded and asked back to the respondent in the area where the training was held.

c). Validation was carried out to determine the extent to which the required data reflect the results of accurate data.

d). Data reduction means that unnecessary data must be discarded. In 6 regencies / cities in West Java that were selected as the object of research, a re-check was made on all questions by re-verifying, categorizing and re-checking the completeness. Then, unnecessary data was discarded.

e). Data narrative is that each finding was described in detail and clearly one by one, compiled based on research questions, thereby getting a picture of what was found during the study.

f). Discussions are the part where the findings are interpreted, then given a comment supported by the results of previous research and relevant research results, as well as existing theories and concepts

\section{Result}

The government's commitment through the Ministry of Youth and Sports to improve the professionalism of sports coaching in Indonesia continues to be done with a variety of schemes. One of which is the novice coach training, which becomes one of the priority activities. Novice coach training activities will motivate coaches to always improve their abilities and competencies in order to create potential athletes. Coaches resulted from the training program can create excellent athletes in the future. The rationale of establishing this program is due to the commitment of the Ministry of Youth and Sports to improve human resources in sports. It is due to the given the number of coaches and sports organizations in the area is still limited.

As a manager and an organizer of sports, The Ministry of Youth and Sports has been working hard to implement programs to improve the quality of national sports. One of them is by continuing to equip knowledge to the coaches, the spearhead of improving athletes' achievement. Improving sports performance can be supported through various activities, such as training, workshops, seminars, refreshment, and coaching clinics. In order to improve the professionalism of sports management and the capacity of sports organizations, the Ministry of Youth and Sports through the Deputy for Sports Performance Improvement has conducted training activities for 100000 novice-level sports coaches and instructors throughout Indonesia. The training was carried out in almost all cities / regencies in Indonesia. The existence of this program will have a positive impact on the development of sports achievements in Indonesia. It is expected that of 100000 novice coaches, one coach will guide one potential athlete, in accordance with the training motto.

From Figure 1, it can be seen that the distribution of novice coach trainees, amounting to 100,000 trainees, of which 40,000 are responsible for the governing body of the sports branch (IOCO), and 60000 are under the authority of the Dean forum of the Faculties of Sports and Health Education at some University-Based Education (FPOK LPTK). The details of the 100000 novice coach training participants can be seen in table 1 . 


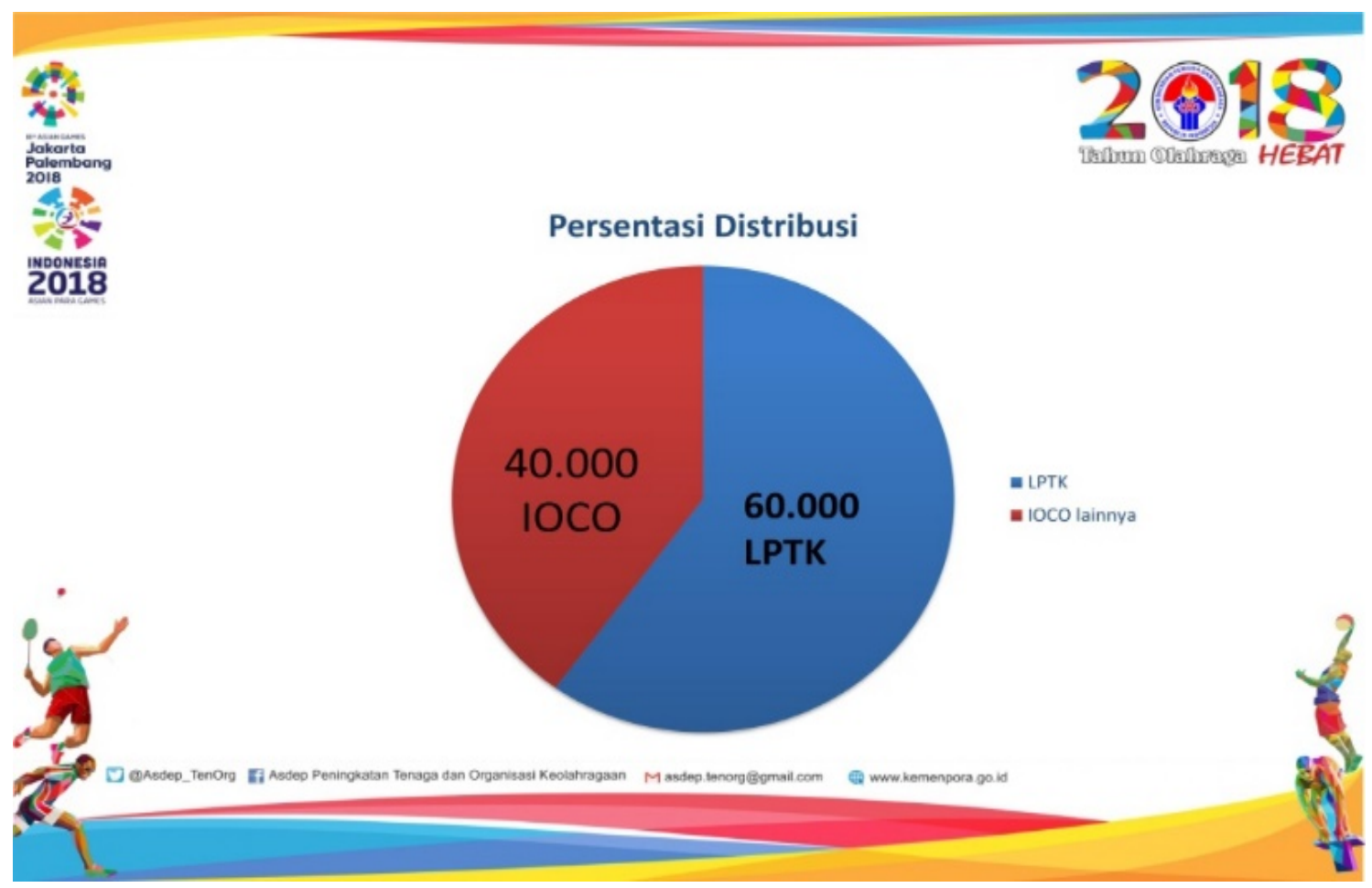

Figure 1. Percentage of Participant Distribution

Table 1. Distribution of Novice Coach Training Participants in Indonesia

\begin{tabular}{|c|c|c|c|}
\hline No & University & Number of Participant & Note \\
\hline 1 & UNIMED & 4000 & \multirow{16}{*}{$\begin{array}{l}\text { Each region provides } 500 \\
\text { participants consisting of: } \\
\text { - } \quad \text { Coaches } \\
\text { - } \quad \text { Teachers } \\
\text { - }\end{array}$} \\
\hline 2 & UNP & 4000 & \\
\hline 3 & UNJ & 5000 & \\
\hline 5 & UNNES & 5000 & \\
\hline 6 & UNESA & 5000 & \\
\hline 7 & UM & 4000 & \\
\hline 8 & UNDISKA & 3000 & \\
\hline 9 & UNIM & 4000 & \\
\hline 10 & UNIMA & 3000 & \\
\hline 11 & UNG & 3000 & \\
\hline 12 & UNY & 5000 & \\
\hline 13 & UNS & 4000 & \\
\hline 14 & UNCEN & 3000 & \\
\hline 15 & UNJA & 3000 & \\
\hline 16 & $\begin{array}{l}\text { Governing body } \\
\text { of sports branch }\end{array}$ & 40000 & \\
\hline \multicolumn{2}{|r|}{ Total } & 100000 & \\
\hline
\end{tabular}

From the data in table 1, it can be seen that there are 60000 participants who are the authority of the dean's forum. Moreover, it can also be seen the distribution for each University that has the Faculty of Sports, get the number of coach trainees who will take part in the training. While the remaining 40000 participants would be given to the governing body of the sports branch or sports institutions. In addition, these institutions must follow the rules and conditions set by the Ministry of Youth and Sports.

From the participants' perceptions, the novice coach training that they participate in can foster motivation, inspiration, and become a place to share experiences of achieving success in the field of coaching. In addition, 
there is an understanding of how to initiate behavioral change to master training skills. Tips for success as a coach will also be obtained. Building dreams through change is a conception of novice coaches prepared in the novice coach training program. Based on the conceptions and perceptions of the novice coaches, towards the educational patterns applied to those who are very concerned about the world of coaching, basically training is a process of transfer of knowledge, skills improvement and changes in behavior or attitudes. All of which practiced directly so that it becomes a separate experience for participants of the training. Novice trainees can learn on their own, manage themselves, be creative in order to achieve good results in accordance with the mechanisms achieved in the training.

The importance of the role of coaches, instructors and sports personnel in Indonesia becomes a full concern of the Ministry of Youth and Sports. The presence of novice trainees in the training will spearhead the development of sports achievements in Indonesia. Participants who attend the novice training activities are expected in the future will be able to increase capacity and quality for the achievement of the mission to achieve the highest achievements in Indonesian sports.

Sports professionals have competencies based on their level. For sports coaches, they are expected to be able to improve the quality of management so that in the future they will be able to encourage sports achievements in regional level. The participants who participated in the training activities varied from sports teachers, sports students, and sports coaches. With the existence of novice coaches training, it can also help local governments, especially for KONI (National Sports Committee of Indonesia) in Regency/City level and the governing body of the sports branch for data collection and mapping of coaches who have not been well recorded, aside from the main objectives to be achieved by the Ministry of Youth and Sports of the novice coach training program.

A good training can provide benefits for participants who participate in this case the novice coach training program. The main objective to be achieved from the training is knowledge. Novice coaches who are newly trained are expected to get enough knowledge to be able to do the work that will be given. Skills are related to novice trainers who are newly trained in which they are expected to be able to perform tasks when placed in a predetermined process. Meanwhile, attitude is related to situations after conducting training, which is expected that the new novice coaches can have interest and awareness on how their works to be done. Novice coach training is very popular across ages.

\section{Discussion}

\subsection{The Meaning of Novice Coach Training}

The Ministry of Youth and Sports has a superior program based on President Joko Widodo's instructions, a training program of 100000 novice coaches. It is a long-term program to improve national sports achievements by strengthening the National Sports System. Through strengthening the foundation of sports development in the regional level, this program is also supported by sports personnel in terms of quantity and quality. Novice coach training is one of the ways taken by the Ministry of Youth and Sports. Novice coach training program is a brief educational effort to provide insights into beginner-level coaches / instructors carried out in a structured manner. As an applied science, coaching has an artistic and empirical meaning. Artistic meaning explains that in its application, it is necessary to pay attention to the unique and varied characteristics of athletes because a training method applied to different athletes sometimes cannot obtain the same results [17]. While the empirical way means the more a coach applies his knowledge, the more diverse the right method he can choose for his athlete [18]. The most fundamental basis of the training profession is a training philosophy whose function is very important because it is a compass for the coaching process so that the training philosophy enlightens the direction and purpose of training [19].

In this training program, the term novice coach was defined as someone who is in charge of preparing a physical, technical, tactical and mental training program for athletes. In training activities there is a head coach who is responsible for organizing and making all with the help of his assistants. A coach is not only required to have experiences and expertise in playing techniques, but also needs to understand the training program procedures from the beginning until the end. In order to get optimal results, a coach is also required to have fast adaptability in understanding the situations and conditions of the athletes he trains. A coach must learn continuously, understand, develop, and practice his knowledge as a form of self-actualization (experience) so that his competence continues to increase. Thus, through a series of these processes, in addition to obtaining a comprehensive understanding of coaching, coaches will also discover and have the art of training.

A coach is the most essential component for successful sports achievements. This is evidenced by the various awards given to the coaches, both from athletes, managerial teams, and even institutions. There are two types of coaches, namely novice and professional coach. Those types have the same goal of improving the quality of various aspects which will be demonstrated through the competition performance in all sports. The thing that distinguishes the two of them is that the novice coaches are not legally contracted, but they are more defined by their dedication and interest in training the athletes. In contrast, professional coaches are legally contracted and are usually defined by their ability and professionalism. Besides, they belong to recognized and legal institutions. Therefore, their 
rights and obligations are fulfilled properly, including financial rights. Therefore, coaches must have a wealth of knowledge and experience in order to carry out their duties properly. The coach is a figure who is noticed by various parties, ranging from athletes, management, and the wider community. In addition, in order to have the ability to train the athletes, they also should have a good attitude. Besides, in order to achieve optimal performance, coaches need to continue innovating to adapt to the demands and developments of the sports trends.

\subsection{The Reason for the Importance of Beginner Trainer Training}

A training is ideally designed to realize the objectives, both the objectives of the organization conducting the training and the objectives of the participants who take part in the training individually. The objectives of the training include: 1) developing expertise, so that work can be completed faster and more effectively; 2) developing knowledge, so that work can be done rationally; 3) developing attitudes, so that the ability to cooperate with fellow employees and leaders can be enhanced [20], [21].

Mesquita, Ribeiro, Santos, \& Morgan [22] stated that the purpose of the training is to help trainees to acquire skills, attitudes, and habits of thinking efficiently and effectively. Understanding the training objectives clearly reveals that training must be a means of meeting the needs of trainees to be able to develop skills, knowledge, attitudes, which can be utilized by the trainees in accordance with their competencies. Therefore, novice coach training becomes important in its implementation as a foundation to create great coach candidates and encouraging the quality of national sports. In line with this, a previous research conducted in Brazil on the analysis of the organizational structure of the program offered by the Brazilian Sports Federation concluded that the development of certain competencies related to the context of performance was very important and theoretical tests or seminars aimed at showing the competencies needed at each level of certification can also be done [23]. Furthermore, another research adds that to better assess trainers' experiences in the programs carried out by enriching the quality of activities developed so that the creation of a collaborative learning environment that is supported by real experience will enable coaches to discuss and reflect in order to make them construct their knowledge [24].

\subsection{Benefits of Novice Coach Training Results}

Novice coach trainees get a change in attitudes, knowledge, and skills gained from the training process. The Ministry of Youth and Sports, especially the Deputy of Sports Achievement, a leading sector in the development of sports achievement, has big responsibilities to improve sports achievements in Indonesia. National sporting achievements have suffered a long drought at various international events. One of the efforts made was by conducting a training program for 100000 novice coaches. With this training approach, it is expected that it can provide broad opportunities for novice coaches to develop their capacity to achieve the title of professional coaches.

In the novice coach training, the activities carried out are not only conveying the materials. However, it can also provide knowledge about the main principles of coaching that can align abilities, related to the growth and development of young athletes. Understanding of the trainer, understanding of the values of athlete development, motivation theory, affective and psychomotor aspects, by providing direct work experience to trainees based on the types of coaches based on their expertise and professional fields by paying attention to the attitudes, skills and results of each training. Empathy is the basis of the coaching spirit. Increased empathy makes services to others increase as well. The higher the attitude of one's service combined with good character; the coaching competence will increase. Novice coach training is an effort to make someone care and useful for others. One's coaching competence is determined by how much empathy or level of concern they have for others.

Other research states that training can be applied as a tool to improve the appearance / ability of individuals or groups in order to improve skills [25]. Certain skills are taught so that the coaches can carry out tasks according to the desired standard. Training can also improve attitudes towards work, towards leaders or towards trained athletes. Besides, other benefits of training are improving service standards [26].

\section{Conclusions}

Based on the results of this study, it can be concluded that the training of novice coaches, which became the flagship program of the Ministry of Youth and Sports, was carried out as an effort to improve the achievement of national sports. Training is an activity designed to develop human resources through a series of planned identification, assessment and learning processes. Education and training are expected to bring sportsmanship values, work ethic motivation, instill good values, and support excellent programs from the Ministry of Youth and Sports. Changes in mindset, values and paradigms, as well as other theories that are given during the training process take place and are carried out through the process of learning by doing or on job training.

The aim of the mass novice coach training by the Ministry of Youth and Sports is an effort to improve the quality of human resources, especially in sports. The existence of this training can also help local governments, especially for KONI (National Sports Committee of Indonesia) in Regency/City level and the governing body 
of the sports branch to record and map the trainers who have not been well recorded.

Novice coach training is expected to be a tool for coaches who have an interest and awareness of their work to keep improving their competence. Another benefit that can be gained from the results of the novice coach training is that the coaches of sports at the regional level will no longer have difficulties in finding coaches for coaching programs for their clubs and sports branches. The Central Government and Local Governments have the right to direct, guide, assist and supervise the organization of sports activities in accordance with statutory regulations. The Central Government and Regional Governments are obliged to provide services and facilities as well as guarantee the implementation of sports activities for every citizen without discrimination. The Central Government has the task of establishing and implementing policies and standardization of the sports sector nationally. Meanwhile, the Regional Government has the duty to implement policies and coordinate the development of sports and carry out standardization of the sports sector at the regional level.

\subsection{Recommendations}

In terms of the importance of developing the competence of novice coaches in Indonesia, the results of this research have not provided adequate information because the trainees did not get an assessment from training speakers and supervisors. For future researchers, it is suggested to carry out more comprehensive and comparative research, for example, training conducted at regional sports branch and national sports branch by involving various policy makers as well as where the training is further extended to regions that have the potential to develop a model training coaching for sports achievements. In addition, it is also necessary to consider the use of motivation levels in sports coaching aspects by taking into account the factors causing weaknesses in the preparation of instruments.

In a training organization, there are several components that are interrelated with one another. The training component is one of the factors that influences the training quality and becomes the main key in compiling a training program that includes all sources and facilities that support training activities in the training. It includes curriculum, training objectives, learning resources, learning facilities, costs needed and training managers. Furthermore, the trainees also have a variety of characteristics such as knowledge, skills and expertise, gender, education, learning needs, socio-cultural background, economic background and study habits.

It is very important for policy makers and stakeholders to develop sports achievements and implement the ten pillars of policy to implement coaching in sports. It needs to be done to build a solid foundation in the systematic development of national sports.

\section{REFERENCES}

[1] M. A. Leeds, P. Von Allmen, and V. A. Matheson, The Economics of Sports, 6th ed., no. February. New York: Routledge, 2016.

[2] B. Houlihan, "Sport, national identity and public,” Nations Natl., vol. 3, no. I, pp. 113-137, 1997.

[3] V. De Bosscher, The global sporting arms race: An international comparative study on sports policy factors leading to international sporting success. Adelaide: Meyer \& Meyer Verlag, 2008.

[4] B. Houlihan and A. White, The politics of sports development: Development of sport or development through sport? London: Psychology Press, 2002.

[5] L. Nur, A. Suherman, and H. Subarjah, "The Use of Global Positioning System (GPS) Polars to Determine Motion Intensity,” J. Eng. Sci. Technol., vol. 14, no. 4, pp. 21322139, 2019.

[6] Kemenpora, "Kemenpora Siap Melaksanakan 4 Program Prioritas Percepatan Pembangunan Sepakbola Nasional,” 2017. [Online]. Available: https://bssn.go.id/kemenpora-sia p-melaksanakan-4-program-prioritas-percepatan-pembangu nan-sepakbola-nasional/. [Accessed: 02-Jun-2020].

[7] Kemenpora, "Menpora Ingin Pelatihan Fisik dan Instruktur Olahraga Bisa Lahirkan Atlet Berkualitas,” 2018. [Online]. Available:

http://www.kemenpora.go.id/index/preview/berita/13006. [Accessed: 02-Jun-2020].

[8] J. Knight, “Instructional Coaching.," Sch. Adm., vol. 63, no. 4, p. 36, 2006.

[9] D. S. Knight, M. Hock, and J. Knight, "Designing instructional coaching," Instr. Theor. Model. A Learn. Paradig. Educ., vol. 4, pp. 269-286, 2016.

[10] J. A. Marsh and F. Martorell, "How Instructional Coaches Support Data- Driven Decision Making,” Educ. Policy, vol. 24, no. 6, pp. 872-907, 2010.

[11] Florida Department of Education, “Just Read, Florida!," 2004. [Online]. Available: http://www.fldoe.org/academics/ standards/just-read-fl/. [Accessed: 02-Jun-2020].

[12] L. Nur, P. M. Setiadi, Y. Kusdinar, and A. A. Malik, "Electronic rubric for motivation in physical education," J. Phys. Conf. Ser., vol. 1318, p. 12129, Oct. 2019.

[13] L. Nur et al., "Comparison of Two Types of Instruction in Physical Education,” Int. J. Psychosoc. Rehabil., vol. 24, no. 10, pp. 1785-1793, 2020.

[14] P. E. White et al., "Ensuring implementation success : how should coach injury prevention education be improved if we want coaches to deliver safety programmes during training sessions ?," Br J Sport. Med, vol. 48, pp. 402-403, 2014.

[15] J. W. Creswell, Qualitative Inquiry \& Research Design 
Choosing Among Five Approaches, 3rd ed. London: SAGE Publications, Inc., 2013.

[16] M. A. Xu and G. B. Storr, "Learning the Concept of Researcher as Instrument in Qualitative Research,” Qual. Rep., vol. 17, p. 42, 2012.

[17] W. Welsch, "Sport-viewed aesthetically, and even as art?," Filoz. Vestn., vol. 20, no. 2, 2016.

[18] G. Demers and M. H. Audet, "What we know about the experiences of women beginner coaches," Can. J. Women Coach., vol. 8, no. 1, pp. 1-8, 2007.

[19] D. Baker, A. U. League, and P. Team, "Designing, implementing and coaching strength training programs for beginners and intermediate level athletes-part 1: Designing the program," Strength Cond. Coach Champaign, vol. 5, pp. 11-20, 1998

[20] M. S. Hagen, "Managerial coaching: A review of the literature,” Perform. Improv. Q., vol. 24, no. 4, pp. 17-39, 2012.

[21] Y. A. O. Wang, "New orientation of training objectives for university social sports majors [J],” J. Wuhan Inst. Phys. Educ., vol. 10, 2006.

[22] I. Mesquita, J. Ribeiro, S. Santos, and K. Morgan, “Coach learning and coach education: Portuguese expert coaches' perspective,” Sport Psychol., vol. 28, no. 2, pp. 124-136, 2014.

[23] M. Weimer, Learner-centered teaching: Five key changes to practice, 2nd ed. San Francisco, CA: Jossey-Bass, 2012.

[24] M. Milistetd et al., "Coaches' development in Brazil : structure of sports organizational programmes Coaches' development in Brazil : structure of sports," Sport. Coach. Rev. ISSN, vol. 5, no. 2, pp. 138-152, 2016.

[25] S. A. Vella, L. G. Oades, and T. P. Crowe, “A pilot test of transformational leadership training for sports coaches: Impact on the developmental experiences of adolescent athletes,” Int. J. Sports Sci. Coach., vol. 8, no. 3, pp. 513530, 2013.

[26] V. S. Rangel et al., “A descriptive analysis of instructional coaches' data use in science science,” Sch. Eff. Sch. Improv., vol. 28, no. 2, pp. 217-241, 2017. 